\title{
FERRAMENTA "5S" APLICADA EM UMA EMPRESA DE USINAGEM: UM ESTUDO DE CASO
}

Congresso Nacional Online de Empreendedorismo, 3ạ edição, de 06/12/2021 a 08/12/2021 ISBN dos Anais: 978-65-81152-30-7

CHIME; Darlan Oliveira ${ }^{1}$, SILVA; Gabriel Candido da ${ }^{2}$, SANTOS; Italo Coutinho dos ${ }^{3}$, OLIVEIRA; Muriel Batista de ${ }^{4}$, SILVÉRIO; Adriano Serra 5

\section{RESUMO}

A filosofia $5 \mathrm{~S}$ de origem japonesa, foi um marco importantíssimo na recuperação após a 2a Guerra Mundial, ao qual deixou sequelas na população, na sociedade e na estrutura da nação japonesa. A reestruturação pós-guerra foi tão eficiente que ficou denominado como milagre econômico japonês, partindo de boas gestões governamentais e muita dedicação. Assim veio surgir o sistema 5S, desenvolvido inicialmente pelo Engenheiro Químico, Kaoru Ishikawa em 1950. Marcado por muitas destruições no cenário nacional, sistema produtivo, organizacional, limpeza, higiene, segurança e disciplina, acabou gerando uma grande deficiência competitiva no país. Com a crise instalada na década de 50 , surgiu a ferramenta de qualidade" $5 S^{\prime}$, que se consolidou no ambiente japonês e vem sendo base para gestão qualidade atualmente. A ferramenta $5 s$ é um conceito, é uma atitude de vida e é uma prática muito simples de ser implantada nas organizações públicas e privadas. Tal ferramenta tem o fundamento de transformar o ambiente das organizações que desejam fazer melhorias, mantendo a competitividade do negócio como uma necessidade nos dias atuais. Mesmo havendo interesse na utilização da ferramenta, muitas organizações desistem pelas dificuldades encontradas na implementação. Neste trabalho foi feito um estudo bibliográfico de toda estrutura do método"5S" por meio de estudo de caso. Foi feita uma descrição detalhada de como implantouu-se a ferramenta em uma oganização do ramo de usinagem de peças automotiva. Após a implantação da ferramenta, pode-se observar que a mesma padronizou, melhorou a organização, layout, otimizou o tempo, gerou disciplina, comprometimento e comodidade de cada colaborador dentro do setor, tornando a empresa mais competitiva.

PALAVRAS-CHAVE: 5S, Qualidade Total, Competitividade, Gestão 